OPEN ACCESS

Edited by:

Donato Giovannelli,

Earth-Life Science Institute, Japan

Reviewed by: Michael J. Wilkins,

Ohio State University, USA

Zachary B. Freedman

West Virginia University, USA

*Correspondence:

Pauliina Rajala

pauliina.rajala@vtt.fi

Malin Bomberg

malin.bomberg@vtt.fi

Specialty section:

This article was submitted to Microbiological Chemistry and

Geomicrobiology,

a section of the journal

Frontiers in Microbiology

Received: 03 December 2016

Accepted: 28 February 2017

Published: 17 March 2017

Citation:

Rajala P and Bomberg M (2017) Reactivation of Deep Subsurface Microbial Community in Response to Methane or Methanol Amendment.

Front. Microbiol. 8:431.

doi: 10.3389/fmicb.2017.00431

\section{Reactivation of Deep Subsurface Microbial Community in Response to Methane or Methanol Amendment}

\author{
Pauliina Rajala ${ }^{1 *}$ and Malin Bomberg ${ }^{1,2 *}$ \\ ${ }^{1}$ Materials Performance, VTT Technical Research Centre of Finland, Espoo, Finland, ${ }^{2}$ Material Processing and \\ Geotechnology, VTT Technical Research Centre of Finland, Espoo, Finland
}

Microbial communities in deep subsurface environments comprise a large portion of Earth's biomass, but the microbial activity in these habitats is largely unknown. Here, we studied how microorganisms from two isolated groundwater fractures at 180 and $500 \mathrm{~m}$ depths of the Outokumpu Deep Drillhole (Finland) responded to methane or methanol amendment, in the presence or absence of sulfate as an additional electron acceptor. Methane is a plausible intermediate in the deep subsurface carbon cycle, and electron acceptors such as sulfate are critical components for oxidation processes. In fact, the majority of the available carbon in the Outokumpu deep biosphere is present as methane. Methanol is an intermediate of methane oxidation, but may also be produced through degradation of organic matter. The fracture fluid samples were incubated in vitro with methane or methanol in the presence or absence of sulfate as electron acceptor. The metabolic response of microbial communities was measured by staining the microbial cells with fluorescent redox sensitive dye combined with flow cytometry, and DNA or cDNA-derived amplicon sequencing. The microbial community of the fracture zone at the $180 \mathrm{~m}$ depth was originally considerably more respiratory active and 10-fold more numerous ( $10^{5}$ cells $\mathrm{ml}^{-1}$ at $180 \mathrm{~m}$ depth and $10^{4}$ cells $\mathrm{ml}^{-1}$ at $500 \mathrm{~m}$ depth) than the community of the fracture zone at the $500 \mathrm{~m}$. However, the dormant microbial community at the $500 \mathrm{~m}$ depth rapidly reactivated their transcription and respiration systems in the presence of methane or methanol, whereas in the shallower fracture zone only a small sub-population was able to utilize the newly available carbon source. In addition, the composition of substrate activated microbial communities differed at both depths from original microbial communities. The results demonstrate that OTUs representing minor groups of the total microbial communities play an important role when microbial communities face changes in environmental conditions.

Keywords: deep biosphere, deep life, carbon, methane, methanol, methanotrophy

\section{INTRODUCTION}

The Fennoscandian Shield, i.e., the exposed Precambrian northwest segment of the East European Craton, preserves some of the oldest geological records of Earth. Studies conducted in several terrestrial deep sites have reported diverse microbial communities extending several kilometers into the Earth's crystalline bedrock (Pedersen, 1997; Haveman and Pedersen, 1999; Sass and Cypionka, 2004; Wu et al., 2015). Microbial communities in deep subsurface environments have 
been estimated to comprise a large portion of Earth's biomass (McMahon and Parnell, 2014) and to have a great impact on the elemental cycles in the deep biosphere (Gadd, 2010). The deep groundwater in crystalline continental crust, such as the one of the Fennoscandian Shield, is independent of photosynthetic carbon and energy production. Alternative means of carbon assimilation, such as inorganic carbon fixation or methane oxidation, may be important to support the microbial communities in these conditions. Chemolithoautotrophic organisms are thought to be the primary producers in deep crystalline bedrock environments (Pedersen, 1997, 2000).

Microorganisms in the deep, nutrient limited biosphere are believed to conduct only little metabolic activity due to low nutrient availability in these environments (Jørgensen, 2011; Hoehler and Jørgensen, 2013). Dormancy refers to an ability to enter a reversible state of low metabolic activity under unfavorable environmental conditions. By remaining in dormant state the microorganisms lower their energetic expenditures. The dormant microorganisms generate a seed bank that may activate following beneficial environmental change (Lennon and Jones, 2011). However, dormant microorganisms must invest resources into resting structures and the machinery that is needed for transitioning into and out of a dormant state (Lennon and Jones, 2011). In addition, low amount of maintenance and survival energy is still required ensure the long-term viability of dormant microorganisms (van Bodegom, 2007; Hoehler and Jørgensen, 2013).

The Outokumpu Deep Drillhole, located in eastern Finland, provides access to study isolated aquifers in the crystalline bedrock in the Paleoproterozoic part of the Fennoscandian Shield (Kukkonen, 2011). The bedrock in Outokumpu is composed of several geochemically different rock types. These include metasediments, ophiolite-derived altered ultramafic rocks and pegmatitic granite (Ahonen et al., 2011). The drillhole reaches a total depth of $2516 \mathrm{~m}$ and spans several fluid-filled fracture zones. Formation waters in these fracture zones are old, highly saline, reducing and have low organic carbon content. The dissolved gas phase, of which $\mathrm{CH}_{4}$ covers up to 80 vol-\%, is abundant (Kietäväinen et al., 2013). The fracture waters have been categorized to five water types, type I $(180 \mathrm{~m})$, type II (500-967 m), type III (1500 m), type IV (1820-2260 m) and type V $(2300 \mathrm{~m})$ (Kietäväinen et al., 2013). The type I water has characteristically high $\mathrm{pH}$ (around 10) and higher alkalinity than the other water types in Outokumpu. High $\mathrm{pH}$ in the drillhole water column may originate from concrete casing within the uppermost $30 \mathrm{~m}$ of the drillhole, and during long-term purging of the sealed-off $180 \mathrm{~m}$ fracture zone, the $\mathrm{pH}$ of the native aquifer fluid dropped to a stable level of 8.5. Water type II contains the highest amount of dissolved gases in the whole water column, of which approximately $75 \%\left(22-32 \mathrm{mmol} \mathrm{l}^{-1}\right)$ is methane. A diverse bacterial and archaeal community has been detected down to $2300 \mathrm{~m}$ depth in the drillhole (Purkamo et al., 2013, 2015, 2016; Nyyssönen et al., 2014). These communities vary at different sampling depths in response to prevailing lithology and hydrogeochemistry (Purkamo et al., 2014, 2016). Simple one-carbon compounds, such as methane and methanol are important intermediates in the deep subsurface carbon cycle, and electron acceptors such as sulfate are critical components in the oxidation processes (Kietäväinen and Purkamo, 2015). Methane $\left(\mathrm{CH}_{4}\right)$ is a key compound in the global carbon cycle and a dominant gas in many Precambrian continental bedrock formations (reviewed by Kietäväinen and Purkamo, 2015). In the shallow subsurface $\mathrm{CH}_{4}$ is mainly produced by anaerobic digestion of organic matter. Deeper in the geological strata $\mathrm{CH}_{4}$ is found in large quantities within sedimentary formations (Arthur and Cole, 2014). Many aspects of origin, source, and cycling of $\mathrm{CH}_{4}$ in deep continental bedrock environments still remain poorly understood (Kietäväinen and Purkamo, 2015). The study of methane cycling is important in order to understand deep subsurface ecosystems, such as those of the Outokumpu deep subsurface. The microbial communities in the Outokumpu deep subsurface have earlier been demonstrated to contain genes involved in methane cycling, indicating both methanogenesis and methanotrophy (Nyyssönen et al., 2014; Purkamo et al., 2015; Rajala et al., 2015). Methanol may be produced through degradation of recalcitrant organic compounds present in, e.g., black schist (Petsch, 2001). Additionally, Nyyssönen et al. (2014) suggested possibility of methylotrophic methanogenesis on Outokumpu deep drillhole water column.

The aim of present work was to determine the activity of microbial communities of two isolated bedrock fractures at 180 and $500 \mathrm{~m}$ depths of the Outokumpu deep subsurface and ability of the dormant fraction of these microbial communities to re-activate. Methane or methanol amendments were used as activating substances in the presence or absence of sulfate as an electron acceptor. The fracture fluid samples were incubated in vitro with methane or methanol in the presence or absence of sulfate as electron acceptor. Highthroughput amplicon sequencing of bacterial and archaeal 16S rRNA genes and gene transcripts were used to identify and characterize the microorganisms that rapidly activate their metabolism in response to methane or methanol. Metabolic response was measured also by staining the microbial cells with fluorescent dyes that indicate respiratory activity. One of the main objectives of this study was thus to determine the microbial community activity and identity of microorganisms responding to methane or methanol in Outokumpu deep biosphere.

\section{MATERIALS AND METHODS}

\section{Description of the Outokumpu Deep Drillhole}

The Outokumpu deep drillhole is situated in Outokumpu, eastern Finland $\left(62^{\circ} 43^{\prime} 04^{\prime \prime} \mathrm{N}, 29^{\circ} 3^{\prime} 43^{\prime \prime} \mathrm{E}\right)$, in a Paleoproterozoic sequence consisting of metasediments, ophiolite-derived altered ultramafic rocks and pegmatitic granite (Ahonen et al., 2011). The Outokumpu mica gneiss- and granite-dominated rock association represents typical Fennoscandian bedrock. A $22 \mathrm{~cm}$ wide drillhole was drilled in 2004-2005 to a total depth of $2516 \mathrm{~m}$ and spans several independent bedrock 
fracture zones (Kukkonen, 2011; Kietäväinen et al., 2013) through Paleoproterozoic, approximately 2 Ga old, bedrock. The lithology, hydrogeochemistry and gas composition of the drillhole and fracture zones have been described previously (Ahonen et al., 2011; Kietäväinen et al., 2013; Purkamo et al., 2013; Nyyssönen et al., 2014). The fracture zones at 180 and $500 \mathrm{~m}$ depth are situated in a metasedimentary rock sequence, predominated by mica schist/biotite gneiss (Purkamo et al., 2014). The residence time for the fracture waters have been estimated to be between 20 and $50 \mathrm{Ma}$ (Kietäväinen et al., 2014). The two fracture zones investigated here have previously been described in detail (Purkamo et al., 2016). In brief, the concentration of sulfate detected at 180 and $500 \mathrm{~m}$ was 1.5 and $1.0 \mathrm{mg} \mathrm{l}^{-1}$, respectively, in the original fracture water. At $500 \mathrm{~m}$ depth, the gas to water ratio was 0.7 and methane contributed with $22 \mathrm{mmol} \mathrm{l}^{-1}$ gas (Kietäväinen et al., 2013). The methane concentration at $180 \mathrm{~m}$ is not known.

\section{Sample Collection}

Deep subsurface fracture fluids were collected in October 2010 (500 $\mathrm{m}$ fracture) and June 2012 (180 $\mathrm{m}$ fracture). The fracture zones in question were isolated from the rest of the drillhole by inflatable packers (Ahonen et al., 2011). The sampling was conducted as described previously (Purkamo et al., 2013, 2016). The isolated fracture zones were purged for 21-42 days, depending on the water yield of the correspondent fracture. Care was taken to ensure that the pumping rate did not exceed the rate of inflow from the fracture zone. Temperature, $\mathrm{pH}$, electrical conductivity $\left(E_{\mathrm{c}}\right)$, concentration of $\mathrm{O}_{2}$ and redox potential $\left(E_{\mathrm{h}}\right)$ of the pumped fluid was continuously monitored in a flowthrough cell and have been reported previously (Purkamo et al., 2016).

The fluid from both fracture zones was collected in the field into sterile, acid-washed $2000 \mathrm{ml}$ glass bottles (Schott, Germany) in an anaerobic chamber (MBraun, Germany). Biomass for RNA and DNA extraction describing the original microbial communities was collected from two duplicate $500 \mathrm{ml}$ samples for each nucleic acid fraction on $0.22 \mu \mathrm{m}$ filters as described earlier (Rajala et al., 2015). In order to preserve the microbial RNA, the sample processing time was kept short and filters were frozen on dry ice immediately after sample collection and maintained at $-80^{\circ} \mathrm{C}$ until nucleic acid isolation.

\section{Induction of Microbial Activity by Methane or Methanol}

The microbial communities' response to methane (final concentration $90 \mathrm{mM}$ ) (referred here as $\mathrm{CH}_{4}$ ) and methanol (final concentration $0.2 \mathrm{mM}$ ) (referred here as $\mathrm{MetOH}$ ) was examined by introducing substrates to aliquots of sample fluid $(500 \mathrm{ml})$. Sulfate (final concentration $0.375 \mathrm{mM}$, referred here as $\mathrm{SO}_{4}$ ) was added in addition of $\mathrm{CH}_{4}$ and $\mathrm{MetOH}$ to study if addition of possible electron acceptor changes microbial communities interactions in methane/methanol metabolisms. Sample water was divided in to sets of three parallel $500 \mathrm{ml}$ subsamples to be treated with four different substrate combinations. $\mathrm{MetOH}$ and $\mathrm{SO}_{4}$ were added to samples in an anaerobic glove box and $\mathrm{CH}_{4}$ was added through the air-tight rubber cap with $\mathrm{N}_{2}$-flushed syringe and needle. Methanol and sulfate were made anoxic prior to use by sterile $\mathrm{N}_{2}$ gas flush for $30 \mathrm{~min}$. After the substrate addition, the samples were incubated for $2 \mathrm{~h}$ at $14^{\circ} \mathrm{C}$ in a shaker ( $\left.45 \mathrm{rpm}\right)$. The biomass from the incubated samples was collected on $0.22 \mu \mathrm{m}$ filters. The filters were cut from the filtration funnels with a sterile scalpel and were immediately frozen on dry ice and maintained at $-80^{\circ} \mathrm{C}$ until RNA isolation.

\section{Nucleic Acid Extraction}

DNA was extracted from the filters containing the microbial biomass from the original fracture water (baseline situation) using the PowerWater DNA Isolation kit (MoBio Laboratories, Inc., Carlsbad, CA, USA) in accordance with the manufacturer's protocol. RNA from both original fracture water and activated samples was extracted from filter membranes using the PowerWater RNA Isolation kit (MoBio Laboratories, Inc., Carlsbad, CA, USA), including DNase, in accordance with the manufacturer's protocol. Negative reagent controls for nucleic acid extractions were included in each extraction.

\section{Reverse Transcription}

The presence of residual DNA in the RNA extracts was excluded by running a PCR with bacterial universal primers U968f and U1401r (Nübel et al., 1996) using the RNA extract as template. No PCR product was obtained, and it was thus assumed that the RNA extracts did not contain residual DNA and they were submitted to cDNA synthesis. The extracted RNA was converted to cDNA by reverse transcriptase-PCR using the Superscript III First Strand Synthesis SuperMix (Invitrogen, Carlsbad, CA, USA) as described previously (Rajala et al., 2015).

\section{Amplicon Libraries and Sequencing}

The amplification libraries for high throughput sequencing on the Ion Torrent PGM platform (Thermo Fisher Scientific) were prepared by PCR from two replicate DNA samples. Bacterial $16 \mathrm{~S}$ rRNA genes were amplified with primers S-D-Bact-0341-bS-17/S-D-Bact-0785-a-A-21 (Herlemann et al., 2011), targeting the variable region V3-V4 of the 16S rRNA gene, archaeal $16 \mathrm{~S}$ rRNA genes with primers S-D-Arch-0349-a-S-17/S-D-Arch0787-a-A-20 (Klindworth et al., 2013), targeting the V4 region of the gene. PCR amplification was performed in parallel $25 \mu \mathrm{l}$ reactions for every sample containing $1 \times \mathrm{MyTaq}^{\mathrm{TM}}$ Red Mix (Bioline, London, UK), $20 \mathrm{pmol}$ of each primer, up to $25 \mu \mathrm{l}$ nuclease-free water (Sigma, St. Louis, MO, USA) and $2 \mu \mathrm{l}$ of template. The PCR program consisted of an initial denaturation step at $95^{\circ} \mathrm{C}$ for $3 \mathrm{~min}, 35$ cycles for bacteria and 40 cycles for archaea of $15 \mathrm{~s}$ at $95{ }^{\circ} \mathrm{C}, 15 \mathrm{~s}$ at $50^{\circ} \mathrm{C}$ and $15 \mathrm{~s}$ at $72^{\circ} \mathrm{C}$. A final elongation step of $30 \mathrm{~s}$ was performed at $72^{\circ} \mathrm{C}$. Correct size of the PCR products was verified with agarose gel electrophoresis. Amplicon libraries were sent to Bioser, University of Oulu (Finland) for sequencing on the Ion Torrent PGM equipment (Thermo Fisher Scientific), and amplicons were purified and size selected to include only 400-600 bp amplicons 
on a Shimadzu capillary electrophoresis (Kyoto, Japan) prior to sequencing.

\section{Sequence Analysis}

The sequence reads obtained from Ion Torrent sequencing were subjected to quality control using the QIIME-software Version 1.9 (Caporaso et al., 2010) using a minimum quality score of 20 , minimum and maximum sequence length of 200 and $600 \mathrm{bp}$, respectively, maximum primer mismatch of two nucleotides (nt) and maximum homopolymer stretches of eight nt. Adapters, barcodes and primers were removed from the sequence reads, and chimeric sequence reads were removed from the dataset with the USEARCH-algorithm (Edgar, 2010) by de novo detection and through similarity searches against the Greengenes reference dataset (Version gg_13_5) (DeSantis et al., 2006) with bacterial and archaeal sequences. OTUs were picked at $97 \%$ sequence homology against the Greengenes database, and de novo OTUs were picked from a randomly subsampled sequence subset that failed the closedreference OTU-picking stage. Singleton OTUs, i.e., OTUs that were represented by a single sequence, were filtered from the dataset. Taxonomy from domain to species level was assigned to OTUs via representative OTU sequences with the Ribosomal Database Project (RDP) classifier algorithm at a minimum of $80 \%$ confidence (Wang et al., 2007). Sequences that did not get any taxonomic assignments were removed from the data sets. Alpha diversity calculations were performed on the absolute OUT abundance data as well as on data normalized to 1000 sequence reads per sample for better comparison between samples. Samples with less than 1000 sequence reads were not normalized.

The sequences were deposited in the European Nucleotide Archive (ENA ${ }^{1}$ ) under accession number PRJEB18131.

\section{Statistical Analyses and Data Visualization}

Alpha-diversity measures (observed OTUs, Chaol OTU richness and Shannon diversity index) were calculated based on the OTU abundance data outputted by QIIME using the Phyloseq package in R (R Development Core Team, 2013; McMurdie and Holmes, 2015) and visualized using ggplot2. The similarity of the archaeal and bacterial communities between the different treatments was tested by principal coordinate analysis (PCoA) using the Phyloseq package in R. The analysis was performed using the OTU abundance data outputted by QIIME. The BrayCurtis distance model was used for both analyses. Eigen values for the variance explained by the PCoA dimensions were calculated on 999 permutations using vegan (Oksanen et al., 2016) in R. An UPGMA tree clustering the samples according to similarity in the OTU profiles and a heatmap was calculated using the 1000 most abundant OTUs with the Bray-Curtis similarity model using phyloseq in R. Statistically significant differences in number of observed OTUs, Chaol-estimated richness and Shannon diversity between treatment types (original DNA and RNA, amendments) and between the different depths was analyzed

${ }^{1}$ https://www.ebi.ac.uk/ with one-way ANOVA, Tukey's pairwise test, Kruskal-Wallis and Mann-Whitney pairwise test using the PAST software (Hammer et al., 2001).

\section{Induction of Respiration and Transcription by Addition of Substrates}

The activating effect of methane or methanol on microbial communities was identified by the redox indicating dye 5cyano-2,3-ditolyl tetrazolium chloride (CTC, Polysciences Inc., Warrington, PA, USA). $50 \mathrm{ml}$ sterile, acid-washed glass serum bottles (Wheaton, NJ, USA) were flushed with sterile $\mathrm{N}_{2}$ gas for $30 \mathrm{~min}$, each containing $0.55 \mathrm{ml} 50 \mathrm{mM}$ CTC dye, and sealed with sterile butyl rubber stoppers (Bellco Glass Inc., Vineland, NJ, USA) and open top aluminum crimp caps (Sigma, St. Louis, MO, USA). Fracture fluid, after 4 weeks of starvation, was aliquoted $(5 \mathrm{ml})$ under anoxic atmosphere through the butyl rubber stoppers into the sealed infusion bottles using a $\mathrm{N}_{2}$ flushed sterile syringe and needle. The bottles were amended with filter-sterilized $\mathrm{CH}_{4}(9 \mathrm{mM})$ or anoxic filter-sterilized methanol $(0.2 \mathrm{mM})$ with or without sulfate (anoxic, filter-sterilized, final concentration $0.375 \mathrm{mM}$ ).

The samples were incubated together with the CTC dye for $6 \mathrm{~h}$, according to the manufacturers recommendations, at $+14^{\circ} \mathrm{C}$ on a shaker ( $45 \mathrm{rpm})$, after which $0.5 \mathrm{ml}$ glycerol-TE buffer was added to the samples for preservation at $-80^{\circ} \mathrm{C}$ according to the protocol by the Single Cell Genomics Center ${ }^{2}$. Briefly the samples were divided into $1 \mathrm{ml}$ aliquots in sterile cryo-tubes and immediately frozen in liquid $\mathrm{N}_{2}$ and stored at $-80^{\circ} \mathrm{C}$. A nondyed reference sample was prepared and preserved in the same way as the dyed samples.

The CTC-dyed and un-dyed fracture fluid aliquots were carefully thawed on ice prior to screening by flow cytometry (BD FACSaria flow cytometer, Becton Dickinson, Franklin Lakes, NJ, USA). Samples were injected into a sterile phosphate buffered saline (PBS) flow stream and fluorescence was detected using a $655 \mathrm{~nm}$ long pass and 675/20 nm band pass filters. For excitation of CTC, an argon laser was used $(488 \mathrm{~nm})$. To detect the active respiratory cells, simultaneous measurements of forward light scatter (relative size), side light scatter (cell granularity), and CTC fluorescence emission were used, by setting the PMT voltage to 250, 250, and 500 volts, respectively. The side scatter threshold was set to 2000 . To investigate the concentration of respiratory active cells, events were acquired over a time of $30 \mathrm{~s}$ with a flow rate of $10 \mu \mathrm{l} \mathrm{min}{ }^{-1}$ from each sample. The fluorescence signal was plotted to the side scatter and analyzed with the $\mathrm{BD}$ FACSDiva $^{\mathrm{TM}} 5.1$ software (Becton Dickinson, Franklin Lakes, NJ, USA). The CTC positive cells were gated comparing the fluorescence intensities of the dyed to the un-dyed fracture fluid sample.

For comparison total number of cells was determined by staining with 4,6-diamidino-2-phenylindole (DAPI) and microscopying as described by Purkamo et al. (2013) and Rajala et al. (2015).

\footnotetext{
${ }^{2}$ https://scgc.bigelow.org/PDFs/Sample_cryopreservation_glyTE.pdf
} 


\section{RESULTS}

\section{Active Population}

The total number of microbial cells in the fracture fluid at the time of sampling was evaluated by counting DAPI stained cells using epifluorescence microscopy (Rajala et al., 2015). In addition, the proportion of respiratorily active cells was determined by staining using the redox sensitive dye, CTC, and counting the cells using flow cytometry. The number of microbial cells was $3 \times 10^{5} \mathrm{ml}^{-1}$, of which $87 \%$ were respiratory active at the depth of $180 \mathrm{~m}$. At $500 \mathrm{~m}$ depth the number of cells was $6 \times 10^{4} \mathrm{ml}^{-1}$, of which only $0.3 \%$ were active (Figure 1). The microbial population from $500 \mathrm{~m}$ depth responded to the addition of methane and methanol by increasing metabolic activity. The largest increase in metabolic activity (16.3\%) was seen in $\mathrm{CH}_{4}+\mathrm{SO}_{4}$ amended sample (Figure 1). Sulfate alone did not affect the metabolic activity of the microbial community of the $500 \mathrm{~m}$ depth and methane amendment caused slightly lower increase in the activity (11.6\%). Sulfate combined to methanol also increased the activity (9\%) slightly more than methanol alone (5.2\%). The microbial community from the $180 \mathrm{~m}$ depth where the majority of microbial community was respiratory active did not respond in the same way to the amendment of methane or methanol substrates or sulfate as the community at $500 \mathrm{~m}$ but the activity of community remained low (Figure 1).

\section{Bacterial Community}

Proteobacteria accounted for the majority of the bacterial communities at both 180 and $500 \mathrm{~m}$ depths, but substrate addition changed the 16S rRNA profile at both depths. At the $180 \mathrm{~m}$ depth the original fracture water community (DNA and RNA) consisted of Betaproteobacteria, Clostridia, Bacteroidia and Anaerolineae (Figure 2A). After methane or methanol addition the detected rRNA profile of RNA contained mainly Gammaproteobacteria (mainly genus Pseudomonas), with Clostridia and Betaproteobacteria as minor classes (Figure 2A and Supplementary Figure S1). This indicates that the Pseudomonas significantly increased their production of ribosomes as a result of the addition of substrates. There were no major differences between the systems with different substrates added. At the $500 \mathrm{~m}$ depth the original community detected from both the DNA and RNA fractions consisted of Alphaproteobacteria, Actinobacteria and Clostridia (Figure 2B). However, after addition of substrates the $16 \mathrm{~S}$ rRNA profile from RNA was dominated by Alphaproteobacteria (resembling mainly Rhodobacter, minority Caulobacter) and Gammaproteobacteria (resembling Pseudomonas) (Figure 2B and Supplementary Figure S1).

The number of bacterial sequence reads obtained varied between 1116 and 7376 reads per sample with an average number of 3862 bacterial sequence reads per sample (Table 1). The number of observed OTUs obtained from the DNA fraction of the bacterial community of the original fracture water at $180 \mathrm{~m}$ depth was generally higher (411-735 OTUs) than that observed at $500 \mathrm{~m}$ depth (258-328 OTUs) (Table 1). The OTU number detected from the RNA fraction from $180 \mathrm{~m}$ depth was also higher (200-492 OTUs) than that detected from the fraction at $500 \mathrm{~m}$ (124-281 OTUs). The number of OTUs detected in the amended samples was on average

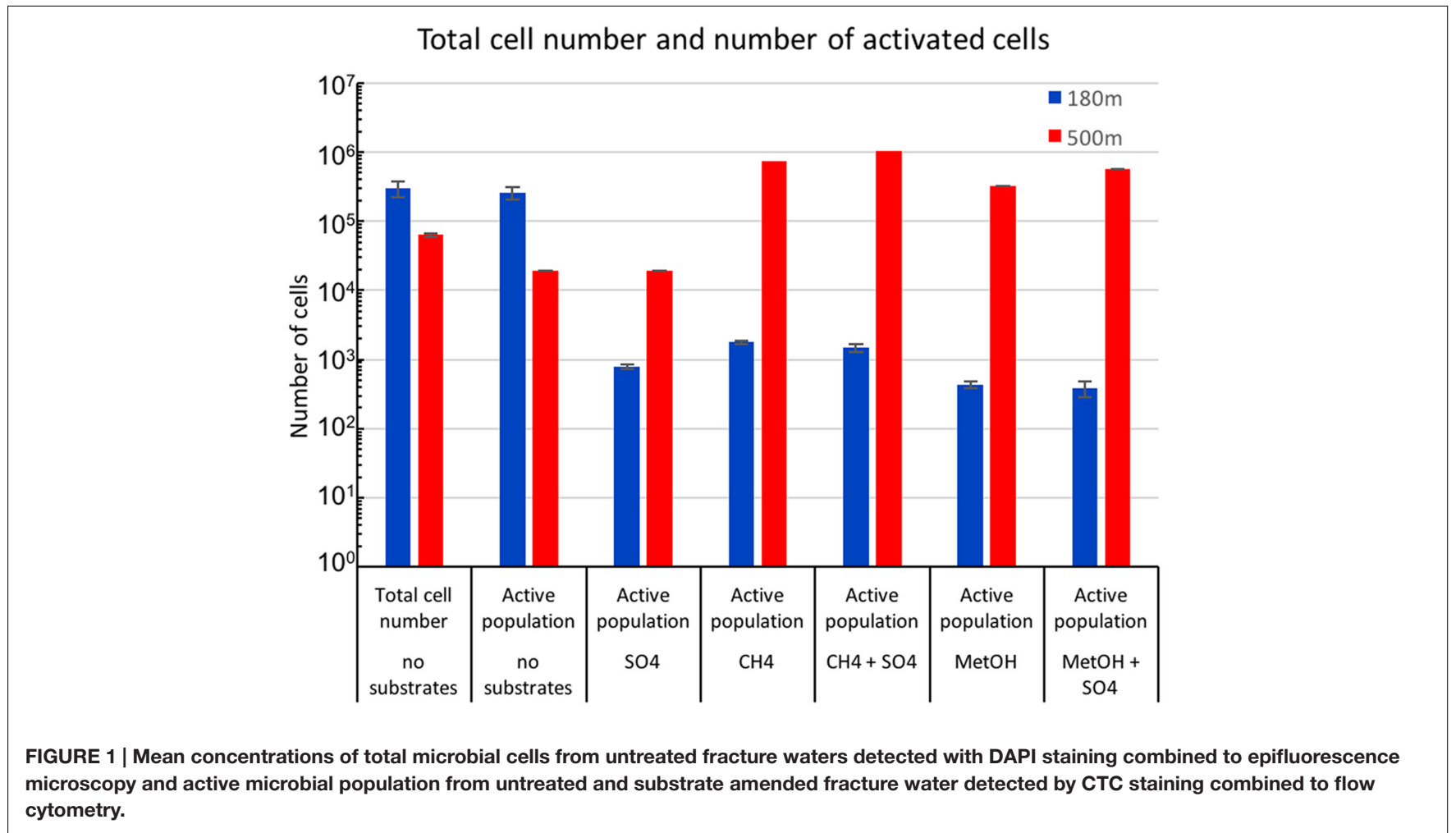




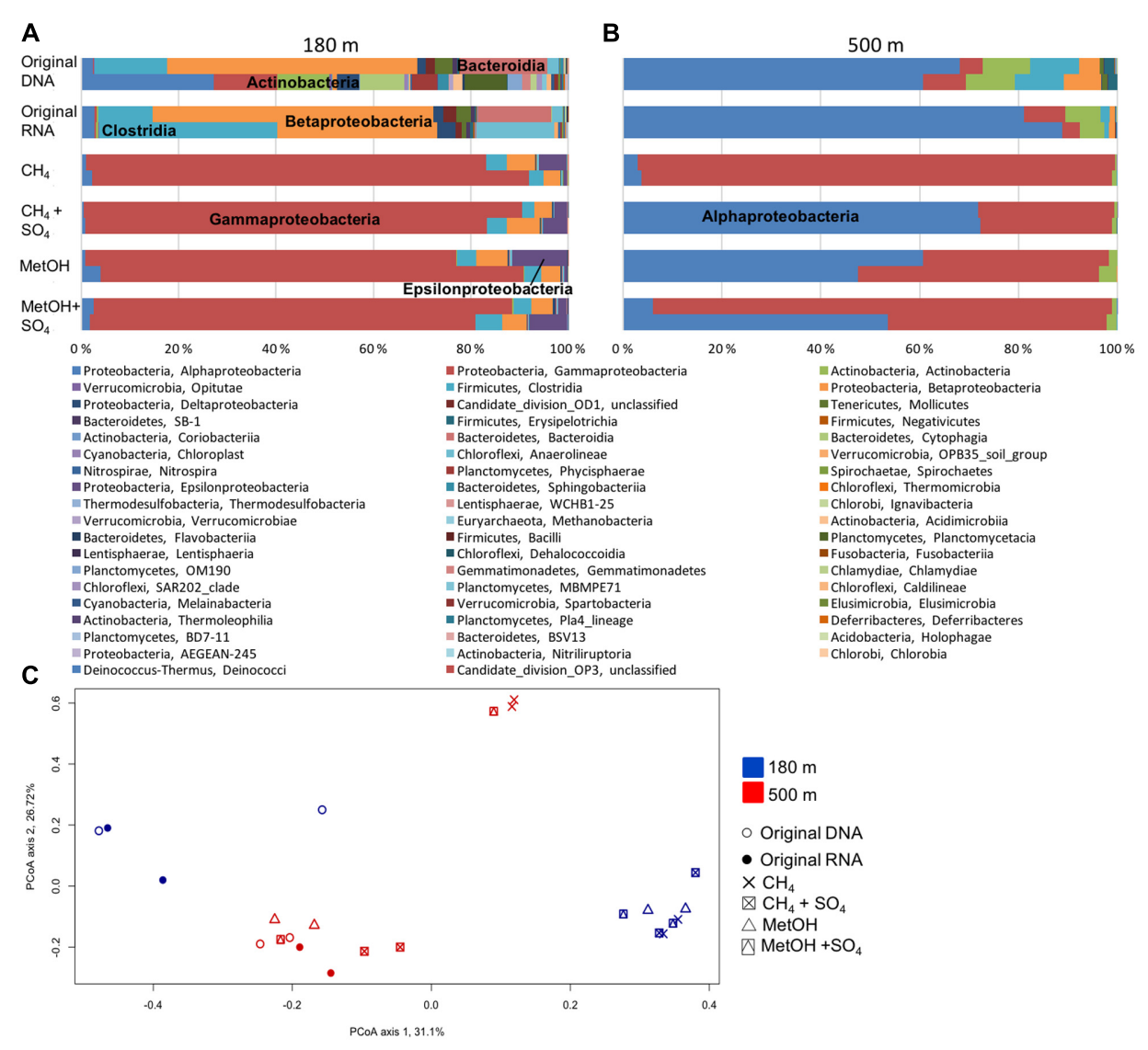

FIGURE 2 | Relative abundance of bacterial community at (A) $180 \mathrm{~m}$ and (B) $500 \mathrm{~m}$ depths based on the bacterial 16S rRNA obtained from DNA (total community) or RNA (active community). (C) Principal coordinate analysis (PCOA) on all the OTU profiles on the Bray-Curtis distance model for the bacterial communities. PCoA axis 1 explains $31.1 \%$ of the variation (eigen value of 999 permutations 1.87) and PCoA axis 2 explains $26.7 \%$ of the variation (eigen value of 999 permutations 1.61).

$302(+/-22.6$ standard error of mean SEM) OTUs in the samples from $180 \mathrm{~m}$ and 227 (+/- 8.1 SEM) OTUs in the samples from $500 \mathrm{~m}$, which was statistically significantly lower (Tukey's pairwise $p<0.01$, Mann-Whitney Bonferroni corrected $p<0.05)$. Taken all observed OTUs into account from the two different depths the average number of OTUs was statistically significantly lower (on average 234 OTUs per sample, SEM $+/-14.5$ OTUs) in the samples from $500 \mathrm{~m}$ compared to the samples from $180 \mathrm{~m}$ (on average 355 OTUs per sample +/42.7 SEM), $p<0.05$ according to Tukey's pairwise test and Mann-Whitney pairwise test with Bonferroni correction. The estimated Chao1 OTU richness was slightly higher in the samples from $180 \mathrm{~m}$ compared to those from $500 \mathrm{~m}$ (Table 1), but no statistically significant differences between the original DNA or RNA fractions or the amended samples between the two depths were observed. The Shannon diversity index $H^{\prime}$ calculated for the bacterial community of the original fracture water at the $180 \mathrm{~m}$ depth was 3.5-5.7 and 3.3-3.7 from the DNA and RNA fractions, respectively. In the substrate amended microcosms the $H^{\prime}$ was between 2.1 and 3.2 in all samples, and the differences were not statistically significant. However, when combining the values obtained from the same treatment of the different depths, the average $H^{\prime}$ from the different amended samples (i.e., methane, methane+sulfate, methanol, or methanol+sulfate) were all statistically significantly lower, between 2.35 and 2.88 $(p<0.05)$ compared to the $H^{\prime}$ from the original DNA (average $H^{\prime}=4.2$ ) and original RNA (average $H^{\prime}=3.1$ ) fractions combined from both depths.

The PCoA analysis demonstrated that the community profiles from the different samples grouped into several groups. The original DNA and RNA samples from the $180 \mathrm{~m}$ depth fell clearly separate from the amended samples (Figure 2C). However, of the samples from $500 \mathrm{~m}$, only one $\mathrm{MetO}+\mathrm{SO}_{4}$ sample and both $\mathrm{CH}_{4}$ samples fell into a different group than the original DNA and RNA samples. Of the $500 \mathrm{~m}$ samples the two $\mathrm{CH}_{4}$-amended samples and one $\mathrm{MetOH}+\mathrm{SO}_{4}$ sample formed their own cluster separate from the other samples from the $500 \mathrm{~m}$ depth (Figure 2C). In addition, the samples from the two depths did not mix on the PCoA plot.

The UPGMA tree and heat map analysis, including the 1000 most abundant OTUs, based of the Bray-Curtis distance model clustered together most of the bacterial communities of the original fracture water determined by both the DNA and RNA fractions from both depths (Figure 3). The bacterial 
TABLE 1 | The alpha-diversity measures (observed OTUs, Chao1 OTU richness and Shannon diversity index $H^{\prime}$ ) calculated for archaeal and bacterial community, numbers 1 and 2 in the sample names refer to two parallel samples included in analysis.

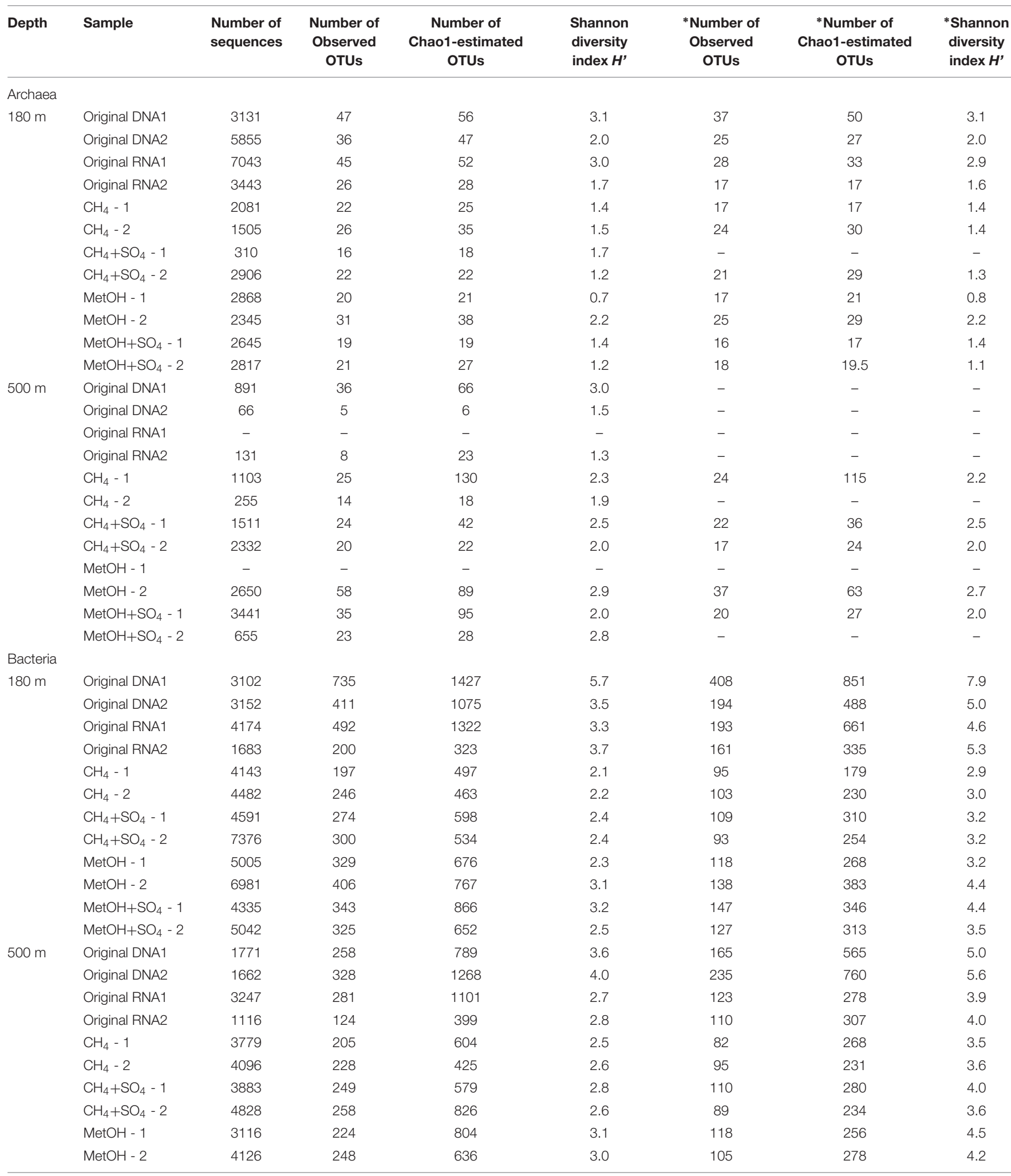

A dash (-) indicates missing data. *subsampled to 1000 sequence reads per sample and shown for samples with <1000 reads. 


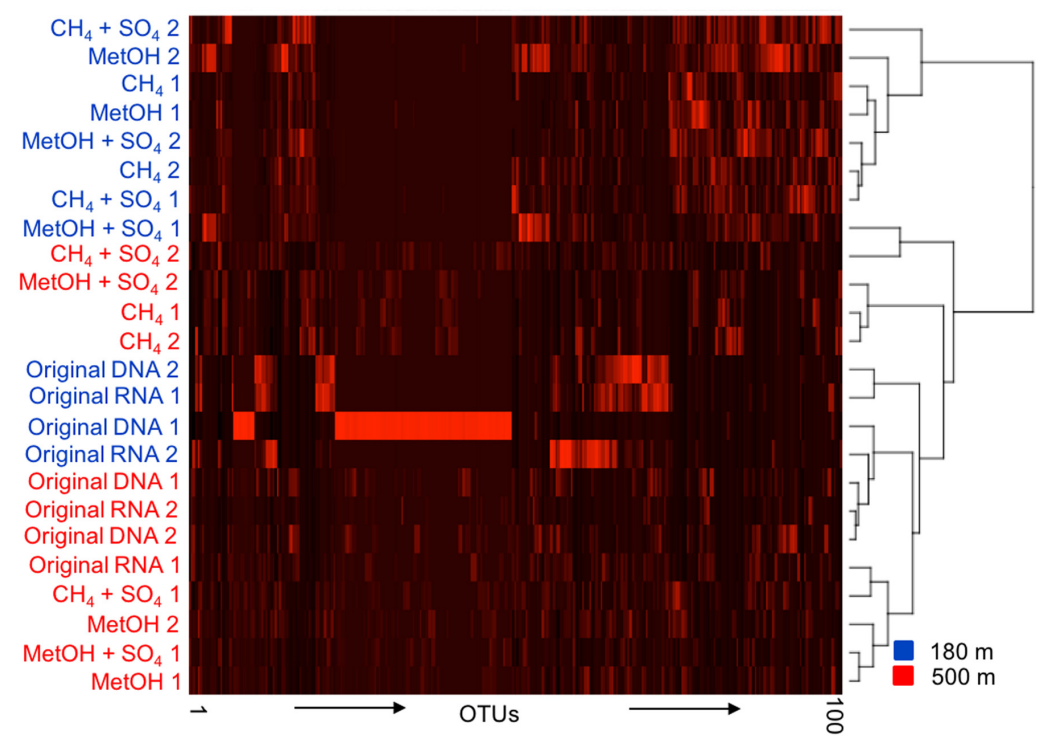

FIGURE 3 | A UPGMA cladogram clustering the samples based on the 100 most abundant OTUs of the bacterial OTU profile according to the Bray-Curtis distance model. Blue indicating $180 \mathrm{~m}$ depth and red indicating $500 \mathrm{~m}$ depth, numbers 1 and 2 refer to two parallel samples included in analysis.

communities from the substrate amended microcosms from $180 \mathrm{~m}$ clustered together in the heat map, while those from $500 \mathrm{~m}$ were split in to two different groups, one containing both $\mathrm{CH}_{4}$ amended communities and the other containing both $\mathrm{MetOH}$ amended communities, with $\mathrm{CH}_{4} / \mathrm{MetOH}+\mathrm{SO}_{4}$ communities divided between them.

\section{Archaeal Community}

The archaeal communities consisted mostly of the Euryarchaeota at both depths. At the $180 \mathrm{~m}$ depth the methane or methanol did not affect the archaeal community composition (Figure 4A and Supplementary Figure S2). The major order was the Methanobacteriales (Supplementary Figure S2). In addition, Methanomicrobiales, Halobacteriales and thaumarcheotal Marine Group I (MGI) were detected (Supplementary Figure S2). At the $500 \mathrm{~m}$ depth the archaeal community structure changed due the methane or methanol availability (Figure 4B). Methanosarcinales, Methanobacteriales, Methanococcales and Methanocellales were detected from the original fracture water samples (Figure 4B and Supplementary Figure S2). As a result of methane or methanol amendments the rRNA profile of RNA changed and was dominated mainly by Halobacteriaceae that was not detected in active community of untreated fracture water, with a small portion of Methanobacteriaceae, 30\% decrease in relative abundance compared to untreated RNA (Supplementary Figure S2).

The number of archaeal sequence reads obtained from the different samples varied between 0 and 4896 reads with an average of 1818 sequence reads per sample. The number of observed archaeal OTUs in the original fracture water was 30-79 and 92-100 OTUs in the DNA and RNA fractions, respectively, while in the substrate amended samples the number of OTUs varied between 26-84 archaeal OTUs. The Chao1-estimated number of OTUs in the original fracture water was 60-130 and 149-232 OTUs in the DNA and RNA fractions, respectively and varied between 31-106 in the substrate amended samples. The $H^{\prime}$ calculated for the original fracture water was 1.9-2.1 and 2.5 in the DNA and RNA fraction, respectively and in the substrate amended samples $H^{\prime}$ varied between 1.8-2.5. At $500 \mathrm{~m}$ the number of observed and estimated OTUs as well as $H^{\prime}$ was generally lower than those at $180 \mathrm{~m}$. The number of observed OTUs in the original fracture water was 3-24 and 4 in the DNA and RNA fractions, respectively. Nevertheless, the number of observed OTUs increased after substrate amendment to between 12-28. The Chaol-estimated number of OTUs in the original fracture water was $4-38$ and 7 , DNA and RNA fractions, respectively, and varied between 17-61 after substrate amendment. The $H^{\prime}$ calculated for the original fracture water at $500 \mathrm{~m}$ depth $0.3-2.2$ and 0.2 for DNA and RNA fractions, respectively. In the substrate amended samples the $H^{\prime}$ varied between 1.3-1.7. Overall, the archaeal community had higher OTU richness and $H^{\prime}$ at $180 \mathrm{~m}$ than $500 \mathrm{~m}$ depth. Nevertheless, there were no statistically significant differences in the number of detected or Chao1-estimated OTUs or $H^{\prime}$ between the different depths or sample types.

At both depths the active archaeal community detected from the RNA fraction in the original fracture water was more diverse than that detected from DNA fractions. The PCoA plotting of the archaeal community showed clear separation between the depths (Figure 4C). The archaeal communities from the $180 \mathrm{~m}$ fracture zone were similar to the ones detected from the original fracture water and generally clustered together both on the PCoA plot and in the UPGMA tree (Figures 4C, 5). Nevertheless, the archaeal community profile of the substrate amended microcosms from the $500 \mathrm{~m}$ fracture zone clustered as a group to the left of the PCoA plot as well as in the UPGMA 

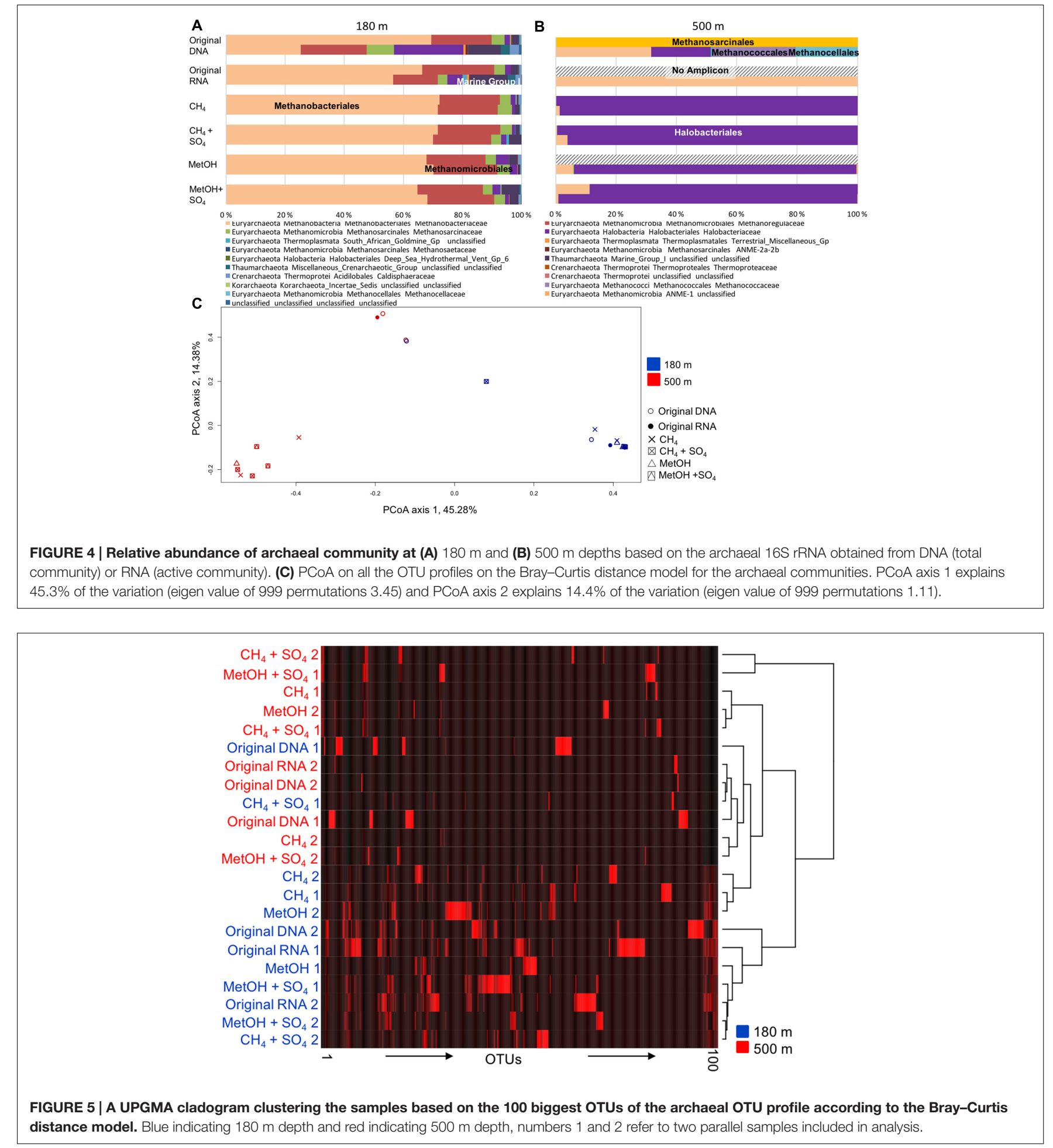

tree. This division indicates that a different population from that dominating in the fracture water at $500 \mathrm{~m}$ depth increased their transcription of ribosomes after substrate amendment allowing for more frequent detection of the ribosomal RNA of this activated population compared to the ribosomes of the dominating taxa.

\section{DISCUSSION}

Microbial communities in deep, nutrient limited subsurface environments of areas with low seismic activity are assumed to express only low metabolic activity when the environmental factors remain stable (Jørgensen and D’Hondt, 2006; Jørgensen, 
2011; Hoehler and Jørgensen, 2013; Lever et al., 2015). In the present study the activity of microbial community differed largely between the two studied fracture zones, the communities of more shallow fracture, $180 \mathrm{~m}$ depth, being more active (87\% of population active) than the communities of deeper fracture zone, $500 \mathrm{~m}$ depth, where only $0.3 \%$ of community was active. By remaining in dormant state the microorganisms lower their energetic expenditures. In ancient isolated subterranean fracture zones, the fluids and the surrounding rock have developed a state of equilibrium where the fluid does not leach chemical substances from the rock without external interference. Occasionally gas may be released causing a stirring in the fluid bringing a flush of nutrients or electron acceptors from the depths, but in general the deep subsurface environment is deemed stable. Nevertheless, due to land movements, such as faults on a longer geological time scale, or geological constructions, new passages for release of pressure (gas bubbles) and fluid flow may occur, and infiltration from meteoric water sources may increase. Mixing of chemically distinct fluid faces has been shown to increase microbial metabolic activity as well as change the metabolic pattern in microbial communities in deep groundwater (Pedersen, 2013). The effect of environmental changes due to for example above mentioned mechanisms was simulated by adding methane or methanol with or without sulfate to the fracture water samples. The microbial community at the $500 \mathrm{~m}$ depth that appeared dormant, gained respiratory activity rapidly when methane became available (11.6-16.3\% activity versus only $0.3 \%$ activity of the population in untreated fracture water) demonstrating the viability and ability of long-isolated microbial communities to utilize introduced substrates, as reported also earlier (Morono et al., 2011; Pedersen, 2013; Rajala et al., 2015). However, in the shallower fracture zone, $180 \mathrm{~m}$ depth, where the ratio of active cells was higher, only a small sub-population was responsive to the methane or methanol amendment. Earlier, Purkamo et al. (2014) suggested that heterotrophic mechanisms such as fermenting could be community supporting strategies at certain depths of Outokumpu deep biosphere. When comparing the activated bacterial population, it was seen that at $180 \mathrm{~m}$ depth the Pseudomonas genus (Gammaproteobacteria) formed the majority of the activated community, whereas in the original community they were in minority. At $500 \mathrm{~m}$ depth Rhodobacterales order (Alphaproteobacteria) were enriched when methane or methanol compounds were available, in addition to Pseudomonas. Earlier Rhodobacterales have demonstrated to utilize methanol efficiently in seawater (Sargeant et al., 2016). Purkamo et al. (2016) suggested that the Pseudomonadaceae-related bacteria are part of the core community in deep crystalline bedrock fractures in Outokumpu and some species affiliating to Pseudomonas are able to grow on methanol (Riis et al., 2003).

The archaeal community at $180 \mathrm{~m}$ did not respond to methane or methanol amendment, whereas the archaeal community profile at $500 \mathrm{~m}$ depth changed from different methanogenic taxa to Halarchaeum after methane or methanol amendment. However, the amount of archaeal 16S rRNA sequence reads was low in untreated samples, both DNA and RNA. This is no surprise, because the detection of archaea from these two depths is difficult as archaea have been shown to be present at only low concentrations of $6.2 \times 10^{3}$ and $8.6 \times 10^{1}$ 16S rRNA gene copies $\mathrm{ml}^{-1}$, while the bacterial 16S rRNA gene concentration reaches $6.3 \times 10^{6}$ and $1.9 \times 10^{6}$ gene copies $\mathrm{ml}^{-1}$ at 180 and $500 \mathrm{~m}$, respectively (Purkamo et al., 2016). Halobacterial groups were only detected from the RNA fraction of the original groundwater, but in the DNA fraction they were not abundant enough to be detected. The fact that the Halarchaeum was detected in the RNA fraction of the substrate induced microcosms indicates that although their relative abundance in the community is low they are able to increase their production of ribosomes upon activation, which allows them to be detected. Our results are in accordance with Manucharova et al. (2016) who showed that archaea belonging to the Halobacteriaceae family can rapidly reactivate after longterm dormancy. The microbial community activating effect of methane addition has been demonstrated also earlier at different terrestrial deep biosphere site (Pedersen, 2013). The microbial community there responded to methane addition by increasing their metabolic activity but the activated community did not correspond to known anaerobic methane oxidizers, which would be most straight forward explanation and the full mechanisms behind activation remained unclear (Pedersen, 2013).

According to the water chemistry the two fracture zones at 180 and $500 \mathrm{~m}$ depth differ from each other greatly and are thought to represent distinctive water types (Kietäväinen et al., 2013). The shallower fracture zone is characterized with higher $\mathrm{pH}$ than the other water types in Outokumpu deep drillhole (Kietäväinen et al., 2013). The fracture water at $500 \mathrm{~m}$ depth, on the other hand, has been demonstrated to contain the highest amount of dissolved gases of all fracture zones crossing the deep drillhole. Approximately 75\% of dissolved gases (22-32 mmol $\mathrm{l}^{-1}$ ) is methane (Kietäväinen et al., 2013). As reviewed by Kietäväinen and Purkamo (2015) the concentration of methane in Outokumpu deep bedrock is high and is in the same range as concentrations detected in the Lupin mine (Canada) and the Beatrix mine (South Africa). The fracture zones are believed to lack hydraulic connections and the exchange of the fracture fluids between the fracture zones is not considered probable (Nyyssönen et al., 2014). The prevalent rock types at these fracture zones are also different. Mica schist-biotite gneiss is the dominating rock type of the fracture at $180 \mathrm{~m}$ depth and Chlorite-sericite schist at $500 \mathrm{~m}$ depth (Purkamo et al., 2016). Despite the differences in the water chemistry and the rock types, the original microbial communities identified from DNA and RNA fractions obtained directly from the fracture waters from both depths clustered closely together in the UPGMA tree (Figures 3, 5). Purkamo et al. (2016) speculated that these two fracture zones might both be in contact with ophiolite-derived rock types and serpentinization could support microbial communities and explain the similarity of the two communities originating from separate fracture zones. In addition, the differences in the two communities was also seen as generally higher bacterial OTU numbers detected from the fracture water from $180 \mathrm{~m}$ compared to that from 
$500 \mathrm{~m}$. This was also previously reported by Purkamo et al. (2016).

Even though the original microbial communities clustered together, the activity of microbial communities at these two fracture zones was very different. At $180 \mathrm{~m} 87 \%$ of the microbial cells stained active without being induced with substrates while only $0.3 \%$ did so at $500 \mathrm{~m}$ depth. Dormancy is estimated to be a common strategy of microorganisms in various environments, especially in deep biosphere (Jørgensen, 2011; Lennon and Jones, 2011). The low activity of the microbial community from $500 \mathrm{~m}$ depth is well in line with previous research, whereas an activity rate of $87 \%$ at $180 \mathrm{~m}$ depth might be considered unusually high for deep terrestrial biosphere (Lennon and Jones, 2011). In addition to higher activity, the cell abundance at $180 \mathrm{~m}$ depth was 10-fold more numerous than at $500 \mathrm{~m}$ depth. However, it is typical that the number of microbial cells decreases as a function of depth (Jägevall et al., 2011; Purkamo et al., 2013; Nyyssönen et al., 2014). The dying of the microbial community with respiratory active dye combined to flow cytometry counting is likely not sensitive enough to detect the microbial community that is viable but respiring at extreme low level in original untreated fracture water samples. How non-sporulating microbial cells, such as those dominating in this study, might exit dormancy and how they might detect permissive environmental conditions is not clear (Dworkin and Shah, 2010; Lennon and Jones, 2011). Dormant cells need to identify growth-promoting conditions, but the wide range of possible conditions makes such a determination challenging (Dworkin and Shah, 2010). This rapid reactivation has only been tested in few studies but some evidence of reactivation within hours has been shown previously (Whitesides and Oliver, 1997).

Our results also support the idea that microorganisms present as minor groups in an environment may play an important role when microbial communities face changes in environmental conditions. These low-abundance groups may represent the so called rare biosphere (Sogin et al., 2006). The rare biosphere does not necessarily need to consist of taxa that generally are hard to find, but they may represent the minority in, for example, the fracture water habitats investigated here. The rare (or low-abundance) taxa may represent a reservoir of genetic diversity that can respond to environmental changes although the metabolic status of these taxa is unclear (Jones and Lennon, 2010). The rare biosphere may be part of the dormant microbial community and as such are thought to serve as an important reservoir to ensure the survival and diversity of a community under stressful environmental situations. These microbes may reactive and multiply following for them beneficial environmental change, a so called seed bank hypothesis (Jones and Lennon, 2010; Lennon and Jones, 2011). It is likely that both of these mechanisms support the response seen in Outokumpu fracture zone communities.

In the Outokumpu deep drillhole water the hydrogen is in isotopic equilibrium, in the system $\mathrm{H}_{2} \mathrm{O}-\mathrm{H}_{2}-\mathrm{CH}_{4}$ at ambient temperatures, which is thought to either indicate equilibration due to long residence time of groundwater or relatively recent in situ production of methane (Kietäväinen et al., 2013). In addition, marker genes for methanogenesis have been previously detected throughout the drillhole water column (Nyyssönen et al., 2014; Purkamo et al., 2016).

\section{CONCLUSION}

The respiratory activity of microbial communities in terrestrial subsurface fracture zones differed largely between fracture zones at 180 and $500 \mathrm{~m}$ depth. Despite apparent dormancy at the $500 \mathrm{~m}$ the microbial community may be able to reactivate rapidly when suitable conditions arise. The microbial community of the fracture zone at $180 \mathrm{~m}$ depth was originally metabolically more active than the community of the fracture zone at $500 \mathrm{~m}$, and only a small sub-population was able to utilize the newly available carbon source. However, the composition of substrate activated microbial communities differed at both depths from the original communities. Our results demonstrate that the minority OTUs of the total community may play an important role when the communities face environmental changes in its living habitat.

\section{AUTHOR CONTRIBUTIONS}

$\mathrm{PR}$ and $\mathrm{MB}$ designed the work, performed the samplings, analyses, and interpreted the data. PR and MB wrote the article.

\section{FUNDING}

The sampling was funded by the Academy of Finland (DeepLifeproject 133847). MB was funded by the Academy of Finland (Methano-project, 261220).

\section{ACKNOWLEDGMENTS}

Maija Nuppunen-Puputti and Lotta Purkamo are thanked for the valuable help during the samplings. Mirva Pyrhönen is thanked for performing part of laboratory work. Ilmo Kukkonen, Lasse Ahonen, and Riikka Kietäväinen from Geological Survey of Finland (GTK) for providing the sampling site and tools for deep underground sampling and performing the analysis of geochemistry. Sirpa Jylhä is thanked for performing the flow cytometry analyses. Merja Itävaara is acknowledged for providing the funding for the field samplings and sample preparation as well as inspiring the study of deep carbon cycling.

\section{SUPPLEMENTARY MATERIAL}

The Supplementary Material for this article can be found online at: http://journal.frontiersin.org/article/10.3389/fmicb.2017. 00431/full\#supplementary-material

FIGURE S1 | The composition of Alphaproteobacteria and Pseudomonadales communities.

FIGURE S2 | The composition of Archaeal, Methanobacteriales and Halobacteriales communities. 


\section{REFERENCES}

Ahonen, L., Kietäväinen, R., Kortelainen, N., Kukkonen, I. T., Pullinen, A., Toppi, T., et al. (2011). Hydrogeological characteristics of the outokumpu deep drill hole. Spec. Pap. Geol. Surv. Finl. 2011, 151-168.

Arthur, M. A., and Cole, D. R. (2014). Unconventional hydrocarbon resources: prospects and problems. Elements 10, 257-264. doi: 10.2113/gselements.10. 4.257

Caporaso, J. G., Kuczynski, J., Stombaugh, J., Bittinger, K., Bushman, F. D., Costello, E. K., et al. (2010). QIIME allows analysis of high-throughput community sequencing data. Nat. Methods 7, 335-336. doi: 10.1038/nmeth. f.303

DeSantis, T. Z., Hugenholtz, P., Larsen, N., Rojas, M., Brodie, E. L., Keller, K., et al. (2006). Greengenes, a chimera-checked 16S rRNA gene database and workbench compatible with ARB. Appl. Environ. Microbiol. 72, 5069-5072. doi: 10.1128/AEM.03006-05

Dworkin, J., and Shah, I. M. (2010). Exit from dormancy in microbial organisms. Nat. Rev. Microbiol. 8, 890-896. doi: 10.1038/nrmicro2453

Edgar, R. C. (2010). Search and clustering orders of magnitude faster than BLAST. Bioinformatics 26, 2460-2461. doi: 10.1093/bioinformatics/btq461

Gadd, G. M. (2010). Metals, minerals and microbes: geomicrobiology and bioremediation. Microbiology 156, 609-643. doi: 10.1099/mic.0.037 $143-0$

Hammer, Ø., Harper, D. A. T., and Ryan, P. D. (2001). PAST: paleontological statistics software package for education and data analysis. Palaeontol. Electron. 4, 1-9.

Haveman, S. A., and Pedersen, K. (1999). Distribution and metabolic diversity of microorganisms in deep igneous rock aquifers of Finland. Geomicrobiol. J. 16, 277-294. doi: 10.1080/014904599270541

Herlemann, D. P., Labrenz, M., Jürgens, K., Bertilsson, S., Waniek, J. J., and Andersson, A. F. (2011). Transitions in bacterial communities along the 2000 $\mathrm{km}$ salinity gradient of the Baltic Sea. ISME J. 5, 1571-1579. doi: 10.1038/ismej. 2011.41

Hoehler, T. M., and Jørgensen, B. B. (2013). Microbial life under extreme energy limitation. Nat. Rev. Microbiol. 11, 83-94. doi: 10.1038/nrmicro2939

Jägevall, S., Rabe, L., and Pedersen, K. (2011). Abundance and diversity of biofilms in natural and artificial aquifers of the Äspö Hard Rock Laboratory, Sweden. Microb. Ecol. 61, 410-422. doi: 10.1007/s00248-010-9761-z

Jones, S. E., and Lennon, J. T. (2010). Dormancy contributes to the maintenance of microbial diversity. Proc. Natl. Acad. Sci. U.S.A. 107, 5881-5886. doi: 10.1073/ pnas.0912765107

Jørgensen, B. B. (2011). Deep subseafloor microbial cells on physiological standby. Proc. Natl. Acad. Sci. U.S.A. 108, 18193-18194. doi: 10.1073/pnas.111542 1108

Jørgensen, B. B., and D’Hondt, S. (2006). A starving majority deep beneath the seafloor. Science 314, 932-934. doi: 10.1126/science.1133796

Kietäväinen, R., Ahonen, L., Kukkonen, I. T., Hendriksson, N., Nyyssönen, M., and Itävaara, M. (2013). Characterisation and isotopic evolution of saline waters of the Outokumpu Deep Drill Hole, Finland-implications for water origin and deep terrestrial biosphere. Appl. Geochem. 32, 37-51. doi: 10.1016/j.apgeochem. 2012.10.013

Kietäväinen, R., Ahonen, L., Kukkonen, I. T., Niedermann, S., and Wiersberg, T. (2014). Noble gas residence times of saline waters within crystalline bedrock, Outokumpu Deep Drill Hole, Finland. Geochim. Cosmochim. Acta 145, 159-174. doi: 10.1016/j.gca.2014.09.012

Kietäväinen, R., and Purkamo, L. (2015). The origin, source, and cycling of methane in deep crystalline rock biosphere. Front. Microbiol. 6:725. doi: $10.3389 /$ fmicb. 2015.00725

Klindworth, A., Pruesse, E., Schweer, T., Peplies, J., Quast, C., Horn, M., et al. (2013). Evaluation of general 16S ribosomal RNA gene PCR primers for classical and next-generation sequencing-based diversity studies. Nucleic Acids Res. 41, 1-11. doi: $10.1093 /$ nar/gks808

Kukkonen, I. T. (ed.) (2011). Outokumpu Deep Drilling Project 2003-2010. Espoo: Geological survey of Finland.

Lennon, J. T., and Jones, S. E. (2011). Microbial seed banks: the ecological and evolutionary implications of dormancy. Nat. Rev. Microbiol. 9, 119-130. doi: $10.1038 /$ nrmicro2504
Lever, M. A., Rogers, K. L., Lloyd, K. G., Overmann, J., Schink, B., Thauer, R. K., et al. (2015). Life under extreme energy limitation: a synthesis of laboratoryand field-based investigations. FEMS Microbiol. Rev. 39, 688-728. doi: 10.1093/ femsre/fuv020

Manucharova, N. A., Trosheva, E. V., Kol'tsova, E. M., Demkina, E. V., Karaevskaya, E. V., Rivkina, E. M., et al. (2016). Characterization of the structure of the prokaryotic complex of Antarctic permafrost by molecular genetic techniques. Microbiology 85, 102-108. doi: 10.1134/S0026261716 010057

McMahon, S., and Parnell, J. (2014). Weighing the deep continental biosphere. FEMS Microbiol. Ecol. 87, 113-120. doi: 10.1111/1574-6941.12196

McMurdie, P., and Holmes, S. (2015). Shiny-phyloseq: web application for interactive microbiome analysis with provenance tracking. Bioinformatics 31, 282-283. doi: 10.1093/bioinformatics/btu616

Morono, Y., Terada, T., Nishizawa, M., Ito, M., Hillion, F., Takahata, N., et al. (2011). Carbon and nitrogen assimilation in deep subseafloor microbial cells. Proc. Natl. Acad. Sci. U.S.A. 108, 18295-18300. doi: 10.1073/pnas.1107763108

Nübel, U., Engelen, B., Felske, A., Snaidr, J., Wieshuber, A., Amann, R. I., et al. (1996). Sequence heterogeneities of genes encoding 16S rRNAs in Paenibacillus polymyxa detected by temperature gradient gel electrophoresis. J. Bacteriol. 178, 5636-5643. doi: 10.1128/jb.178.19.5636-5643.1996

Nyyssönen, M., Hultman, J., Ahonen, L., Kukkonen, I., Paulin, L., Laine, P., et al. (2014). Taxonomically and functionally diverse microbial communities in deep crystalline rocks of the Fennoscandian shield. ISME J. 8, 126-138. doi: 10.1038/ ismej.2013.125

Oksanen, J., Blanchet, F. G., Friendly, M., Kindt, R., Legendre, P., McGlinn, D., et al. (2016). Vegan: Community Ecology Package, R Package Version 2.4-0. Available at: http://CRAN.R-project.org/package=vegan [accessed October 31, 2016].

Pedersen, K. (1997). Microbial life in deep granitic rock. FEMS Microbiol. Rev. 20, 399-414. doi: 10.1016/S0168-6445(97)00022-3

Pedersen, K. (2000). Exploration of deep interterrestrial microbial life: current perspectives. FEMS Microbiol. Lett. 185, 9-16. doi: 10.1111/j.1574-6968.2000. tb09033.x

Pedersen, K. (2013). Metabolic activity of subterranean microbial communities in deep granitic groundwater supplemented with methane and $\mathrm{H}(2)$. ISME J. 7, 839-849. doi: 10.1038/ismej.2012.144

Petsch, S. T. (2001). 14C-Dead living biomass: evidence for microbial assimilation of ancient organic carbon during shale weathering. Science 292, 1127-1131. doi: 10.1126/science.1058332

Purkamo, L., Bomberg, M., Kietäväinen, R., Salavirta, H., Nyyssönen, M., Nuppunen-Puputti, M., et al. (2015). The keystone species of Precambrian deep bedrock biosphere belong to Burkholderiales and Clostridiales. Biogeosci. Discuss. 12, 18103-18150. doi: 10.5194/bgd-12-181032015

Purkamo, L., Bomberg, M., Kietäväinen, R., Salavirta, H., Nyyssönen, M., Nuppunen-Puputti, M., et al. (2016). Microbial co-occurrence patterns in deep Precambrian bedrock fracture fluids. Biogeosciences 13, 3091-3108. doi: 10.5194/bg-13-3091-2016

Purkamo, L., Bomberg, M., Nyyssönen, M., Kukkonen, I., Ahonen, L., and Itävaara, M. (2014). Heterotrophic communities supplied by ancient organic carbon predominate in deep fennoscandian bedrock fluids. Microb. Ecol. 69, 319-332. doi: 10.1007/s00248-014-0490-6

Purkamo, L., Bomberg, M., Nyyssönen, M., Kukkonen, I., Ahonen, L., Kietäväinen, R., et al. (2013). Dissecting the deep biosphere: retrieving authentic microbial communities from packer-isolated deep crystalline bedrock fracture zones. FEMS Microbiol. Ecol. 85, 324-337. doi: 10.1111/1574-6941.12126

R Development Core Team (2013). R: A Language and Environment for Statistical Computing. Available at: http://www.r-project.org/

Rajala, P., Bomberg, M., Kietäväinen, R., Kukkonen, I., Ahonen, L., Nyyssönen, M., et al. (2015). Rapid reactivation of deep subsurface microbes in the presence of C-1 compounds. Microorganisms 3, 17-33. doi: 10.3390/ microorganisms 3010017

Riis, V., Miethe, D., and Babel, W. (2003). Formate-stimulated oxidation of methanol by Pseudomonas putida 9816. Biosci. Biotechnol. Biochem. 67, 684-690. doi: 10.1271/bbb.67.684

Sargeant, S., Murrell, J., Nightingale, P., and Dixon, J. (2016). Seasonal variability in microbial methanol utilisation in coastal waters of the western English Channel. Mar. Ecol. Prog. Ser. 550, 53-64. doi: 10.3354/meps11705 
Sass, H., and Cypionka, H. (2004). Isolation of sulfate-reducing bacteria from the terrestrial deep subsurface and description of Desulfovibrio cavernae sp. nov. Syst. Appl. Microbiol. 27, 541-548. doi: 10.1078/0723202041748181

Sogin, M. L., Morrison, H. G., Huber, J. A., Welch, D. M., Huse, S. M., Neal, P. R., et al. (2006). Microbial diversity in the deep sea and the underexplored rare biosphere. Proc. Natl. Acad. Sci. U.S.A. 103, 12115-12120. doi: 10.1073/pnas. 0605127103

van Bodegom, P. (2007). Microbial maintenance: a critical review on its quantification. Microb. Ecol. 53, 513-523. doi: 10.1007/s00248-006-9049-5

Wang, Q., Garrity, G. M., Tiedje, J. M., and Cole, J. R. (2007). Naive Bayesian classifier for rapid assignment of rRNA sequences into the new bacterial taxonomy. Appl. Environ. Microbiol. 73, 5261-5267. doi: 10.1128/AEM. 00062-07

Whitesides, M. D., and Oliver, J. D. (1997). Resuscitation of Vibrio vulnificus from the viable but nonculturable state. Appl. Environ. Microbiol. 63, 1002-1005.
Wu, X., Holmfeldt, K., Hubalek, V., Lundin, D., Åström, M., Bertilsson, S., et al. (2015). Microbial metagenomes from three aquifers in the Fennoscandian shield terrestrial deep biosphere reveal metabolic partitioning among populations. ISME J. 10, 1192-1203. doi: 10.1038/ismej.2015.185

Conflict of Interest Statement: The authors declare that the research was conducted in the absence of any commercial or financial relationships that could be construed as a potential conflict of interest.

Copyright (c) 2017 Rajala and Bomberg. This is an open-access article distributed under the terms of the Creative Commons Attribution License (CC BY). The use, distribution or reproduction in other forums is permitted, provided the original author(s) or licensor are credited and that the original publication in this journal is cited, in accordance with accepted academic practice. No use, distribution or reproduction is permitted which does not comply with these terms. 